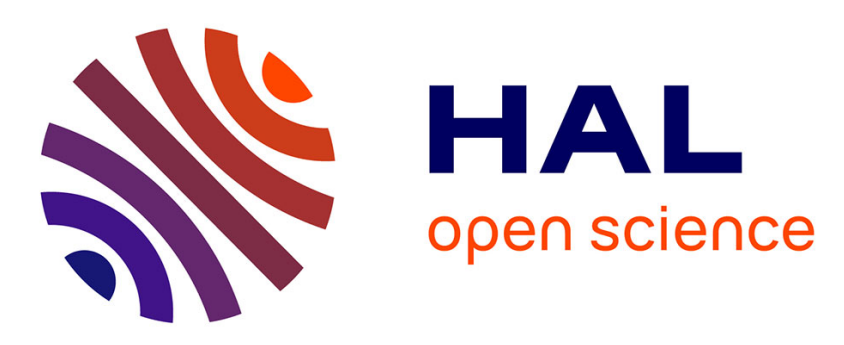

\title{
The Generalized System of Preferences and NGO Activism
}

Lionel Fontagné, Michela Limardi

\section{To cite this version:}

Lionel Fontagné, Michela Limardi. The Generalized System of Preferences and NGO Activism. 2021. halshs-03223795v1

\section{HAL Id: halshs-03223795 \\ https://shs.hal.science/halshs-03223795v1}

Submitted on 11 May 2021 (v1), last revised 22 Jun 2021 (v2)

HAL is a multi-disciplinary open access archive for the deposit and dissemination of scientific research documents, whether they are published or not. The documents may come from teaching and research institutions in France or abroad, or from public or private research centers.
L'archive ouverte pluridisciplinaire HAL, est destinée au dépôt et à la diffusion de documents scientifiques de niveau recherche, publiés ou non, émanant des établissements d'enseignement et de recherche français ou étrangers, des laboratoires publics ou privés. 


\section{Documents de Travail du

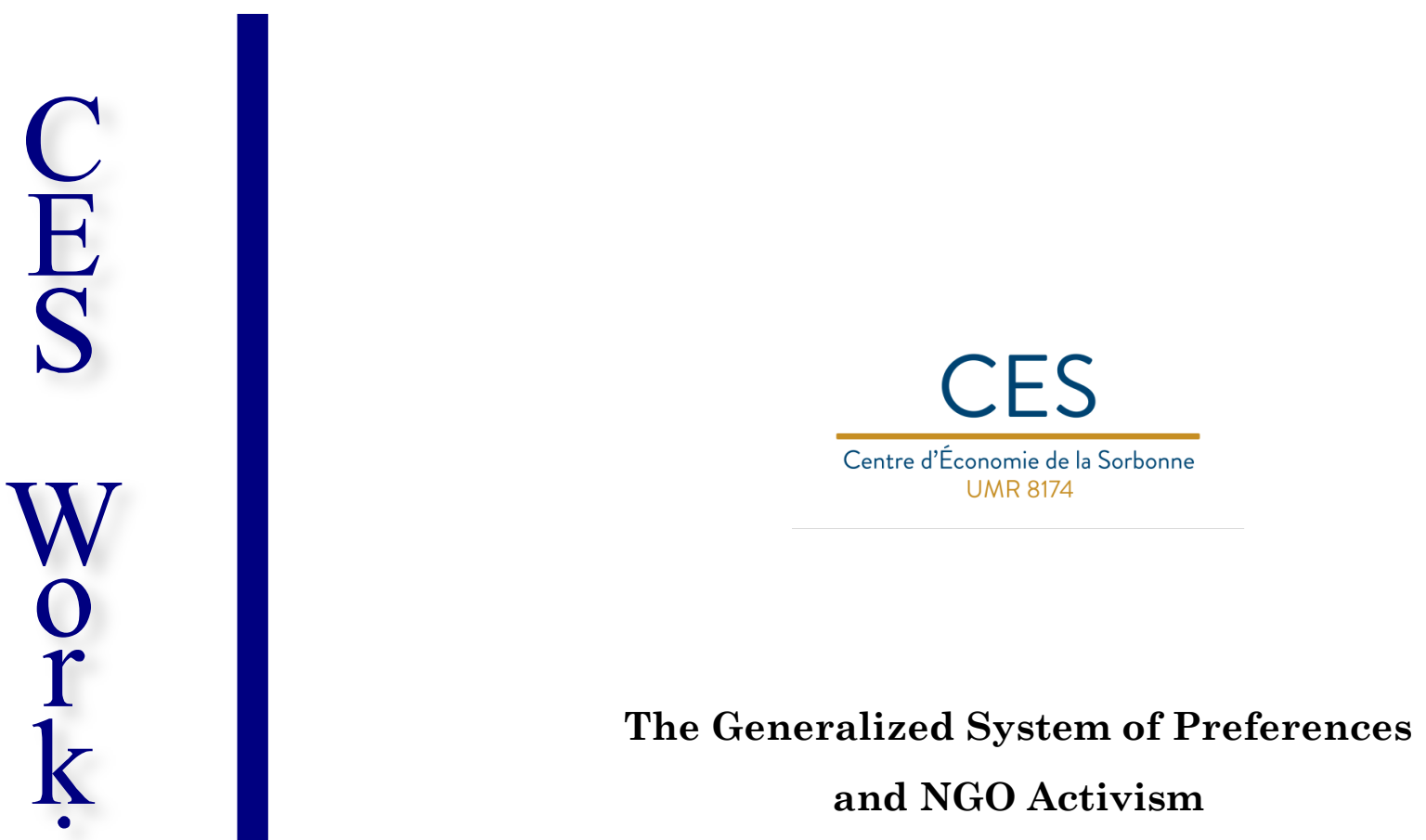

Lionel FonTAGné, Michela LIMARDI

2021.14

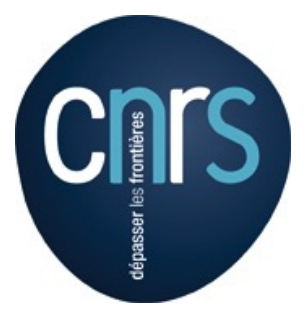




\title{
The Generalized System of Preferences and NGO Activism*
}

\author{
Lionel Fontagné† Michela Limardi ${ }^{\ddagger}$
}

April 30, 2021

\begin{abstract}
Can preferential market access help to enforce Labor Laws in beneficiary countries? The Generalized System of Preferences (GSP) is accorded conditional on compliance with labor rights. The United States scheme leaves room for petitioning and revising the scheme upon request by interest groups. We here focus on such a review episode, and ask whether it led to the better enforcement of domestic Labor Laws in Indonesia. Using data from Indonesian Manufacturing firms, we show that GSP renegotiation combined with the activism of workers' rights groups helped increase firm-level average wages up to the minimumwage level, not only inside but also outside the export sector. GSP leverage allowed labor NGOs to act more effectively by putting the violation of national Labor Laws and poor working conditions under the international spotlight.
\end{abstract}

Keywords: GSP, labor standards, NGOs, wage determination.

JEL: J52, J80.

\footnotetext{
${ }^{*}$ We thank Tito Boeri, Klaus Waelde, John Pencavel, Andrea Ichino, Jose de Sousa, Thierry Verdier, Gani Aldashev, Morgane Tanvé, Bertil Tungodden, Michele Ford, Douglas Kammen and participants at the "NGOs, Development and Globalization seminar" at the Paris School of Economics for their comments, and Margherita Comola for her advice on the data. Lionel Fontagné is grateful for support from the EUR grant ANR-17-EURE-0001. Michela Limardi is grateful for support from the European center for humanities and social sciences (MESHS-Lille, France). The views expressed in this paper are the authors', and do not necessarily reflect those of the institutions to which they belong.

${ }^{\dagger}$ Bank of France, CEPII and PSE. E-mail: lionel.fontagne@banque-france.fr.

$\ddagger$ University of Lille 1 and CES (University Paris 1). E-mail: michela.limardi@ univ-lille1.fr.
} 


\section{Introduction}

Can preferential market access help to enforce Labor Laws in beneficiary countries? The Generalized System of Preferences program (GSP) provides preferential access for certain products in selected lowincome countries. The exporter pays a tariff below (generally duty free) that imposed by default on exports from other members of the World Trade Organization (WTO). Crucially, the GSP is awarded conditional on compliance with labor rights in the beneficiary countries ${ }_{1}^{1}$ One prominent example is the US scheme, which allows for petitioning and the revision of the program upon request by interest groups, such as Trade Unions and NGOs ${ }^{2}$ After investigation, the US may suspend the unilateral preferential treatment if any violation of human rights is uncovered. The threat of removal from the GSP program may thus affect compliance with minimum wages in the export sector of beneficiary countries $3^{3}$ But is there any effect beyond the export sector, which may only be the tip of the iceberg in developing economies? The Indonesian case we choose here as a case study provides convincing evidence of such spillovers.

The aim of this paper is twofold. We first consider the extent to which the threat of removal from the GSP program leads to greater compliance with worker rights, not only inside but also outside the export sector in beneficiary countries. Second, we analyze the role of local NGOs that are involved in the surveillance of the business practices in this potential additional leverage of GSP schemes in the domestic sector. Building on the example of Indonesia, and taking the renegotiation of the GSP with the US in the 1990s as a quasinatural experiment, we show that pressure on the Indonesian government led to tighter implementation of the minimum wage where local NGOs were active. Indonesian NGOs that work on labor issues, defined hereafter as labor NGOs, were heavily involved in the revision of the US GSP in Indonesia. They furnished much of the documentation presented in the petition, and met the GSP team a number of times (Ford, 2006). We hypothesize that the "dialogue" involving NGOs, who defend workers' interests in the beneficiary countries, goes much beyond the legal framework and its enforcement by exporting firms. The whole chain of sub-contractors comes under scrutiny, as well as the most obvious abuses in the sectors of the economy that are not exposed to international markets. All in all, the intrinsic temporary nature of the GSP and the related "dialogue" with local NGOs may reinforce the pressure on the beneficiary country. We exploit the geographical variation of the activity of Indonesian labor NGOs and the exogenous shock, i.e. the deadline of the US GSP revision in Indonesia $4^{4}$ We first carry out a difference-in-difference analysis to estimate the

\footnotetext{
${ }^{1}$ The criteria for selecting countries are discretionary although not discriminatory de jure: they are defined in terms of development level, enforcement of minimal labor rights, or even respect of intellectual property rights. The selection of products is also discretionary, and based inter alia on the competitive pressure exerted on domestic production. The United States (US) scheme adds to this list the enforcement of property rights, respect of arbitration procedures and "equitable and reasonable access to its market" (US GSP Guidebooks, USTR, November 2020).

${ }^{2}$ The US GSP scheme was established by the Trade Act of 1974 and implemented in 1976.

Harrison \& Scorse 2003) and Harrison \& Scorse 2010) provide empirical evidence on the effect of GSP revision on compliance with minimum wages in the export sector in Indonesia.

${ }^{4}$ Table 17 provides the names and district-level locations of Indonesian labor NGOs. Section 5.3 will address the endongeneity issue related to NGO location, by describing the geographical and historical determinants of industrial development and labor unrest
} 
impact of labor NGO activism on the average wage for unskilled workers. We compare firms located in districts with labor NGOs to those in districts without labor NGOs, before and after the US GSP revision in Indonesia. In a second step, we run panel regressions to measure the wage gap, defined as the difference between the minimum wage and the average firm-level wage, in districts where labor NGOs were active and in the period following the US GSP revision. 5

A large literature has called into question the benefits of the GSP program for beneficiary countries (Özden \& Reinhardt, 2005; Gamberoni, 2007; Brenton \& Manchin, 2002, Brown, 1988) 6 However, the impact of the GSP on worker rights has been relatively neglected. Elliott (1998) explains how the leverage of the US program is larger than its (modest) size, possibly because bad practices in beneficiary countries are put under the spotlight during the review process, and all the more so in the case of the withdrawal of the preferences. This leverage is also greater when human rights groups are involved in the petitioning process. Harrison \& Scorse (2003) analyse the impact of the GSP on labor standards in the 1990s, when Indonesia experienced the revision of the GSP by the US for violating labor standards. The main response of the national government was to increase the minimum wage in all provinces. There is strong evidence of an impact on minimum-wage compliance in the export sector. Harrison \& Scorse (2010) focus on antisweatshop activism in the US, and compare the wage growth of workers in foreign-owned and exporting firms in regions that were more exposed to activism (where subcontractors of well-known brands were located) and in targeted sectors before and after the campaigns started. Targeted firms paid higher wages as a result of activism.

Our contribution is to complement the formerly-identified effect of GSP revision on compliance with the minimum wage in the export sector. We show that compliance with Labor Laws increases not only in the export sector but also in the domestic sector. After the GSP revision, average firm-level wages rose where labor NGOs were active in non-compliant firms, i.e. firms paying below the minimum wage. The threat of the removal of preferential tariffs on exports to the US in 1994 induced the Indonesian government to introduce labor reforms (Glasius, 1999). The main decision was to raise the level of the legal minimum wage. However, the unexpected outcome of the international pressure was to increase the fraction of firms paying their employees below the minimum wage 7 Wages are often also set below the minimum level in

\footnotetext{
in Indonesia during the 1980s and 1990s.

${ }^{5}$ Our definition of the wage gap refers more precisely to the "reverse wage gap", i.e. that the average firm-level wage is below the minimum wage, as it is the difference between the legal minimum wage and the average firm-level wage. Firms with average wages below the minimum wage (i.e. non-compliers) have a positive wage gap, while that for firms with average wages above he minimum wage (compliers) is negative.

${ }^{6}$ This may misfire due to the associated tight rules of origin; it may weaken the need to reform own-trade policies in beneficiary countries, and may even induce perverse specialization in less-dynamic sectors (Özden \& Reinhardt 2005) and fail to promote export diversification (Gamberoni 2007, Brenton \& Manchin, 2002). Recent advances in the gravity literature have led to nuanced conclusions regarding the impact on the exports of beneficiary countries (Gil-Pareja et al. 2014). As the benefits of the GSP are limited for developing countries due to limited coverage, it might be preferable to have deep cuts in the MFN tariffs on a multilateral basis notwithstanding the induced erosion of preferences for beneficiary countries (Baldwin \& Murray 1977)

${ }^{7}$ After the 1994 minimum-wage rise following outside pressure by the United States, the fraction of domestic firms in Indonesia paying below the minimum wage rose by around 20 per cent.
} 
other developing countries, due to weak enforcement institutions and workers' lack of knowledge of their rights 8 This occurs more often in domestic firms that are less monitored by labor inspectors and rarely come to the attention of international campaigns 9 The literature on the behavioral effects of minimum wages (Wang, 2012; Falk et al. 2006) underlines that minimum-wage movements change the workers' reference point during wage bargaining with the employer: the minimum wage becomes the reference point in the wage bargain (an anchoring effect) even when wages are below this level. In most developing countries, this is due to the presence of asymmetric information on the minimum wage between the firm and the workers (Wang, 2012). The mechanism that we have in mind is that the technical and legal assistance provided by labor NGOs to workers can reduce this wage gap: information to workers on labor rights and Laws may reduce this asymmetry. Along with local NGO activities, the GSP review provides leverage by putting the violation of national Labor Laws and poor working conditions in the domestic sector under the international spotlight.

The remainder of the paper is organized as follows. In Section 2 we set the stage and explain why Indonesia is an ideal case study for the impact of local NGO activism on compliance with Labor Laws in the domestic sector. Section 3 then presents the data and method used to identify this effect. The fourth section presents the results, and the robustness tests appear in Section 5. The last section concludes.

\section{Setting the stage}

In this section we describe the conditionality of GSP schemes, and explain how NGO petitioning against the violation of workers rights in Indonesia led the Indonesian Government to be more defensive with respect to international criticism.

\subsection{US preferential treatment at risk}

To be eligible for the US GSP scheme ${ }^{10}$ a developing country “ (...) must have taken or is taking steps to afford internationally recognized worker rights, including 1 . the right of association, 2 . the right to organize and bargain collectively, 3. a prohibition on the use of any form of forced or compulsory labor, 4. a minimum age for the employment of children, and a prohibition on the worst forms of child labor, and 5. acceptable conditions of work with respect to minimum wages, hours of work and occupational safety and

\footnotetext{
${ }^{8}$ There exists a recent theoretical and empirical literature analyzing the mechanism behind non-compliance with minimum wages in developing countries (Bhorat et al. 2015 Goraus-Tanska \& Lewandowski 2019. Ham 2018).

${ }^{9}$ See The Fundamentals of Minimum Wage Fixing, ILO 2005.

${ }^{10}$ The US GSP consists of two sub-programs: the standard GSP provides preferential duty-free treatment to a wide range of designated beneficiary countries. The list of products is longer for the least-developed beneficiary countries. A revision to the program in 1984 introduced an annual review and provisions to petition the US Trade Representative to challenge certain countries' eligibility for the program.
} 
health" 11

The US Trade Representative (USTR) carries out an annual GSP review with the possibility of petitioning ${ }^{12}$ and provides recommendations to the President of the United States regarding inter alia the countries to be excluded from the duty-free treatment ${ }^{13}$ If the petition is accepted, the GSP Subcommittee starts an investigation and produces its decision in the Spring of the next year to extend or suspend the GSP program ${ }^{14}$ Formally, the President of the United States then suspends the program of the GSP in response to the violation of labor rights detected in the beneficiary country ${ }^{15}$ As a consequence, beneficiary countries face a trade-off between market access and domestic reform. Our first hypothesis is that beneficiary countries will accept to ratify and implement basic labor rights to reduce the risk of losing the GSP.

\subsection{NGO petitioning against Indonesia}

Indonesia represents a prominent case study, as it has had three US GSP reviews related to worker-rights issues. The first two revisions, in 1987-1988 and 1989-1990, started with a petition filed by the AFLCIO (American Federation of Labor-Congress of Industrial Organization). The level of wages was not covered by these revisions, and the US Government concluded at the end of the investigation that Indonesia had taken appropriate measures to improve the situation. In 1992, a petition filed by Asia Watch and the ILRERF (International Labour Rights Education and Research Fund) was accepted. This time the level of wages, as well as wage enforcement, were one of the areas of particular concern to the United States. The investigations took two years, and there was a real possibility of Indonesia losing its GSP privileges ${ }^{16}$ The deadline for the third GSP review was February 1994 ${ }^{17}$ We focus our analysis on this third US Indonesian GSP revision, and minimum-wage compliance outside the export sector in areas where local labor NGOs were active.

The labor-market policy response of the Indonesian government resulted from a combination of pressure from the US and increased domestic labor unrest (Glasius, 1999). In August and September 1993, just before and during the third US GSP revision, the activities of Indonesian labor NGOs (those that are spe-

\footnotetext{
${ }^{11}$ GSP guide book, Office of the US Trade Representative, December 2019, p.17. There are additional criteria, not reproduced here as they are not relevant for our purpose.

${ }^{12}$ Recommendations to the President are based on hearings and petitions. Hearings involve representatives of the beneficiary country and US petitioners.

13“"The Office of the United States Trade Representative (USTR) will consider petitions to modify the GSP status of GSP beneficiary countries because of country practices; add products to GSP eligibility; remove products from GSP eligibility for one or more countries; waive competitive need limitations (CNLs) [...]”. (Federal Register Vol.83, No.65, April 4th 2018, Notices, p.14540.)

${ }^{14}$ See GSP Guidebook, USTR, April 2018.

${ }^{15}$ The potential leverage of the GSP on the domestic policies of beneficiary countries is reinforced by the fact that revisions can be effected at the product level. We do not address here the impact of the so called "Competitive Need Limitations" corresponding to various cut-offs initiating a withdrawal of the general scheme in November $t+1$ : i) an exporter holds $50 \%$ of the US import market for the product; ii) exports of that product exceed 185 million USD (in 2018).

${ }^{16}$ Glasius (1999) notes, regarding the third US GSP revision, "Indonesia's economic dependence on aid as well as trade contributed to the influence of the United States, because Indonesia feared that termination would have ramifications for other aid and trade programmes."

${ }^{17}$ The deadline for the final decision of the US GSP revision was later extended to August 1994.
} 
cialized in labor rights) intensified. According to Glasius (1999), this was a "trend of an increasing number of educated people pondering over the possible advantage from such external pressure as the latest shown on the GSP issue".

Labor NGOs are new actors among the labor-market organizations in developing countries. These small and mission-oriented organizations differ from other Human-Rights NGOs in that they carry out activities traditionally undertaken by Trade Unions 18 During the Suharto regime in Indonesia, there was one official trade union, closely connected to the ruling political party. Indonesia's first labor NGOs were established between 1973 and 1985, in response to the weakness of the traditional labor movement ${ }^{19}$ These had two main activities: grassroots labor organization and research/policy advocacy on labor issues (Ford, 2006). The first consisted mainly in operations within the industrial sector, where they acted as a substitute for labor unions, outside the factories, under the authoritarian Indonesian regime. Indonesian workers, in the absence of independent Trade Unions, also consulted activists from labor NGOs for technical and legal advice, for instance to establish a wage-bargaining strategy before meetings with employers. Advocacy activity also aimed to improve the situation of industrial workers (Ford, 2006). Indonesian labor NGOs cooperated with international NGOs in order to raise awareness through local and foreign media of the poor working conditions in Indonesia. In 1990, a group of Indonesian labor NGOs created the Forum Solidaritas Untuk Buruh (Forsol Buruh). This network of local NGOs was heavily involved in the review of the US GSP for Indonesia. Forsol Buruh and other Indonesian labor NGOs provided much of the documentation presented in the petition, and met the GSP team a number of times (Ford, 2006). 20

A campaign against military involvement in the 1991 labor dispute was the turning point for labor NGO activities (Gough et al., 2013). In August 1991, workers organised a series of strikes in the fourteen factories of the Gadjah Tunggal group, a large integrated tire manufacturer. The government responded with military repression. Labor NGOs publicly protested against military involvement in the strike, and many activists were arrested. Labor NGOs acquired greater credibility among workers as a result, and became more active in labor issues at the firm level. Over the same period, there was a considerable rise in labor unrest in Indonesia and repressive military intervention. Labor NGOs were also involved in the organization of strikes, and were able to contact national and international media to make public the more violent of the labor conflicts 21

\footnotetext{
${ }^{18}$ Labor NGOs rely on external funding and income generated by their organization, while the primary funding base of labor unions in developing countries remains member contributions (although financial assistance from abroad is becoming increasingly important) (Ford 2009)

${ }^{19}$ Other examples include the activism of labor NGOs in the region of Guangdong in China since the 1990s, which has proliferated and extended from South China to the North (chi Chan 2013), or women's NGOs working with the women's section of the Malaysian Trade Union Congress on many issues (Crinis 2008.

${ }^{20}$ The review team met Forsol Buruh and other labor NGOs in 1993, 1994 and June 1995 (Ford 2006).

${ }^{21}$ The issue of labor unrest in Indonesia during the 1990s and the interaction with labor NGOs will be discussed in more detail in Section 5.3
} 


\subsection{The Indonesian government's response}

The main response of the Indonesian government to this international criticism of labor working conditions was to make substantial concessions regarding the level and implementation of the minimum wage 22 In 1994, when the third US GSP revision was expected to conclude, the minimum wage rose by over 40 per cent in all Indonesian provinces ${ }^{23}$ However, this did not translate into the same rise in individual wages received, due to poor enforcement and worker knowledge of their rights (Rama, 1996). The World Bank Indonesia Jobs Report (2010) states that "The burden of non compliance falls disproportionately on the workers who, arguably, need more income protection: women, temporary staff and low-wage employees. Small firms are more likely to avoid compliance because they are too small to form unions and fall under the radar of labor inspectors". We will focus our analysis particularly on these non-compliant (domestic) firms.

\section{Data and empirical method}

\subsection{Data and descriptive statistics}

The annual Manufacturing Survey of Indonesia, collected and compiled by the Indonesian government statistical agency BPS (Badan Pusat Statistik), is our primary source of wage information. We have observations on around 20,000 firms per year ${ }^{24}$ The dataset covers the period before and after the third US GSP revision in Indonesia: 1991-1996. We consider the period starting in 1991, as this was the year in which labor NGOs started to become more active and recognized as legitimate by industrial workers. We stop in 1996, as the financial crisis and the end of the Suharto regime make any later analysis more difficult to interpret. The second source of information covers labor NGO activism in Indonesia, and relies on a detailed list of labor NGOs compiled by Ford (2009) 25 We use information on labor NGO location at the District level ${ }^{26}$ Districts (kabupaten) are an administrative sub-division of a Province, and have their own local governments and legislative bodies.

\footnotetext{
${ }^{22}$ The minimum wage was one issue considered to be essential by the United States (Glasius 1999). During the first months of 1994, the Indonesian government made other legislative improvements. First, it conceded collective bargaining at firms with over 25 employees, although the Serikat Pekerja Seluruh Indonesia (SPSI - Confederation of Indonesian Workers Union) continued to be recognized as the official union. Second, the Decree that explicitly authorized military intervention in the settlement of labor disputes was repealed, even though this intervention continued in practice (Report of Amnesty International, May 1994). Last, companies that did not comply with labor rights were black-listed and had to pay a fine of 50 USD (Rama 1996)

${ }^{23}$ The minimum wage in Indonesia is fixed annually. The local council at the Province level makes recommendations to the Ministry of Manpower. The issue of the exogeneity of this increase in minimum wage will be discussed in detail in Section 3.2.

${ }^{24}$ The BPS submits an annual questionnaire to all registered Manufacturing establishments with 20 or more employees. The survey includes information on employees (total wages, and the number of skilled and unskilled workers) as well as firm-level characteristics (sector, province, size, ownership, etc.). We will here only use information on unskilled workers (which the survey calls production workers).

${ }^{25}$ The list of the names and locations of Indonesian labor NGOs appears in Table 17.

${ }^{26}$ In the robustness analysis we will use information on the District-level location of other Indonesian humanitarian NGOs, publiclyavailable in the dataset on the website of SMERU, a large Indonesian NGO.
} 
We are especially interested in the gap between the minimum wage in the Province where the firm is located and the average wage at the firm level. The latter is the total wage over the total number of unskilled workers. The minimum wage is fixed each year at the Province level. Our main dependent variable is the wage gap, defined as the difference between the minimum wage and average firm-level wages.

As shown in Table 1, the 1991-1993 wage gap was negative, and then turned positive in 1994. As such, the average number of firms paying average wages below the minimum wage level rose notably after the Indonesian government's minimum-wage increase. In our descriptive statistics we also use the average wage over the minimum wage (the wage ratio) as an additional wage-gap measure: this ratio was below 1 after 199427

Figure 1 shows the trend in minimum wages (the red line) and the wage actually paid (the dashed line) in all Indonesian Provinces. Both trends refer to mean wages, averaged over all Indonesian firms. After 1994, firms paid wages that were below the minimum on average. In Figure 2 we regress the variable wage gap on year, sector and Province dummies, and plot the point estimates: the gap rose remarkably in 1994, 1995 and 1996 ${ }^{28}$ Table 2 shows the number of Indonesian Manufacturing firms, and the number and share of non-compliant firms per year ${ }^{29}$ After 1994, around 60 percent of firms did not comply with the minimum wage. Following the rise in the minimum wage after the US GSP mission in Indonesia, the share of non-compliant firms increased from 46 percent in 1993 to 65 percent in 1994 . We focus our analysis on these non-compliant firms, and consider the variation across space in non-compliance, conditional on the presence of labor NGOs.

\subsection{Identification strategy and empirical method}

In 1992, once the petition filed by two labor-rights organizations had been accepted, the US carried out an investigation of working conditions in Indonesia. The main response of the Indonesian government to this US pressure was to increase the minimum wage in all Provinces. We therefore have good reason to believe that the 1994 minimum-wage rise can be considered as exogenous for the purpose of our analysis, as it was not related to labor-market conditions in Indonesia 30

As noted above, this minimum-wage rise did not produce a proportional increase in firm average wages: in the majority of firms, average wages remained below the minimum wage. We specifically focus on these non-compliant firms and look at District-level wage trends after the minimum-wage increase 31

\footnotetext{
${ }^{27}$ During this period there were two Export Processing Zones (EPZs) in Indonesia at the District level. EPZs provide a series of benefits for foreign investment: export-oriented Manufacturing facilities and streamlined administration. The compliance with Labor Laws, the number of labor inspections and the repression of labor activists was notably different in the EPZs (Sivananthiran 2009). We will exclude EPZ Districts from the analysis to avoid that their particularities regarding labor issues drive the results.

${ }^{28}$ The gap rose from 2000 Rupiah in 1992 to 15000 Rupiah in 1994.

${ }^{29} \mathrm{~A}$ firm is defined as non-compliant if its average wage is below the provincial minimum wage.

${ }^{30}$ The 1996 World Bank report on Indonesia confirms that this raise was essentially due to foreign pressure, independent of the tightness of the Indonesian labor market (Rama 1996).

${ }^{31}$ As a robustness check, we will exclude exporting firms from the sample, to see what happens in firms that were not directly
} 
In non-compliant firms, the minimum wage can still act as a reference point (an anchor) in the wagebargaining process, including for workers paid below the minimum wage (Wang, 2012). The mechanism that we have in mind here is that the technical and legal assistance provided by labor NGOs to workers on labor rights and Laws can shrink this wage gap by reducing information asymmetry.

The minimum wage is set at the Province level, and we know where NGOs are located at the District level, within Provinces. It is important for our identification strategy that labor NGOs were already active in those districts before 1991: their activism is then not an outcome of the US GSP revision and there was no geographical variation in their location over time (Ford, 2009). The majority of labor NGOs were active in Java, essentially for historical reasons ${ }^{32}$ The Indonesian labor movement developed under the influence of Dutch Socialists in Java in the 1910s, when the colonial government had moved to liberalize its social policy (Ford, 2009). In Section 5.3, we will discuss the geographical distribution of labor NGOs in more detail, in order to address the potential endogeneity of their location.

We wish to analyze the average wage difference between Districts with and without labor NGOs, within the same Province ${ }^{33}$ We consider Districts with active labor NGOs as the "treatment" group and those without as the "control" group. Table 3 presents the mean values of the wage gap, the number of workers, the wage ratio and wages over the period prior to treatment (before 1994) in the treatment and control groups, for all firms. There is no statistically-significant difference in the wage gap and average wages between the treatment and control groups before 1994. In contrast, there is a statistically-significant gap after 1994 in the wage gap, average wages and the wage ratio, as shown in Table 4.

Our first objective is to analyze the impact of labor NGO activism on average firm wages, independently of the role of the minimum wage. We thus carry out a difference-in-difference estimation. We exploit the geographical variation in labor NGO activism and the exogenous shock, the deadline of the US GSP revision. Our first dependent variable is the log of the average wage at the firm level. We estimate the following equation:

$$
\ln \text { wage }_{i p d t}=\alpha+\beta_{1} T+\beta_{2} N G O_{d t}+\beta_{3} T * N G O_{d t}+\beta_{4} X_{i d t}+\eta_{p} * \eta_{t}+\eta_{i}+\epsilon_{i d p t}
$$

\footnotetext{
concerned by the GSP revision.

${ }^{32}$ Java is the fourth-largest island in Indonesia but contains over half the country's population. The only city outside Java where labor NGOs were active was Medan, the capital of North Sumatra Province. Java was the center of the Dutch East Indies, and the center of independence conflicts during the 1930s and 1940s.

${ }^{33}$ Labor NGOs essentially operate at the local level, due to their size and limited resources (Ford, 2009).
} 
where $i=$ firm, $d=$ District, $p=$ Province, and $t=$ year

$$
\begin{aligned}
& T=\left\{\begin{array}{l}
1 \text { if year }>1994 \\
0 \text { if year }<1994
\end{array}\right. \\
& N G O=\left\{\begin{array}{l}
1 \text { districts with labor NGOs } \\
0 \text { districts without labor NGOs }
\end{array}\right.
\end{aligned}
$$

Our second objective is to see whether labor NGO activism also affected the wage gap for non-compliant firms. In equation 2, the dependent variable, lnwage gap, is the the log of the difference between the minimum wage and firm-level average wages. The minimum wage is fixed at the Province level. As we have information on labor NGOs' location at the District level (an administrative subdivision of the Province), we can compare the gap between the minimum wage and the average wages of firms in Districts with and without labor NGOs in the same Province.

We estimate equation 2 in a panel regression with firm fixed effects over 1994-1996 (the period after the US GSP revision), rather than a difference-in-difference regression. We do so as the different trends in the minimum wage and average wages before and after 1994 make it difficult to interpret the value and the sign of the coefficient (See Figure 1). As a robustness check, we will carry out two Placebo tests, to see if there is any significant difference between Districts with and without labor NGOs before the US GSP revision and with other human rights NGOs.

$$
\ln \text { wagegap }_{i p d t}=\alpha+\beta_{1} N G O_{d t}+\beta_{4} X_{i d t}+\eta_{p} * \eta_{t}+\eta_{i}+\epsilon_{i d p t}
$$

where $i=$ firm, $d=$ District, $p=$ Province, and $t=$ year

With this equation, we wish to estimate the effect of labor NGO activism after the US GSP revision in non-compliant firms, i.e. firms whose average wage is below the minimum wage ${ }^{34}$ The large 1994 increase in the minimum wage was not followed everywhere by a proportional increase in average firm-level wages: over half of firms did not comply with the new minimum wage after 1994. We are here interested in these non-compliant firms.

To summarize, in equation 1 , we analyse the average wage of unskilled workers for compliant and non compliant firms, while in equation 2, we examine the wage gap, namely the distance between the minimum wage and the average wage of unskilled workers within non compliant firms.

\footnotetext{
${ }^{34}$ In this specification wage gap therefore always takes on values above zero.
} 


\section{Results}

The results from the difference-in-difference estimation of Equation 1 appear in Table 5 We split the sample into non-compliant and compliant firms, and include control variables at the firm level: profit is the value added of the firm less payments to workers; growthK the annual growth in capital stock; perPUBLIC the percentage of the firm owned by the local or central government; and perdompriv the percentage of domestic private ownership of the firm. All of the regressions include firm fixed effects and interactions between Province and year fixed effects, to take into account any annual shock experienced by the Province during the period under analysis. We also include nbskill (the number of skilled workers) in order to control for any change in labor composition within the firm towards skilled labor. We cluster the standard errors at the District level. The coefficient on our main variable of interest, $T * N G O_{d t}$ (the interaction between the NGO dummy at the District level and the time dummy T), is positive and very significant for noncompliant firms: following the US GSP revision, non-compliant firms in Districts with labor NGOs paid higher average wages compared to firms in Districts without labor NGOs. The estimated nbskill coefficient is negative and significant for all firms: within-firm, a greater number of skilled workers is associated with lower unskilled wages 35

In what follows, we restrict our analysis to non-compliant firms, to measure the impact of labor NGO activism for unskilled workers with wages below the minimum, after the significant 1994 rise in the minimum wage. Table 6 shows the results for our main specification (Equation 2). The dependent variable is the firm-level wage gap (in logarithms). Column (1) controls for profit and growthk, and column (2) adds the ownership variables perPUBLIC and perdompriv. All columns include interacted year and Province fixed effect to control for Province-specific time shocks. We cluster standard errors at the District level.

In Table 6 the dummy NGO variable is negative and significant in both specifications: after the US GSP revision, the wage gap was smaller in firms in Districts with labor NGOs, so that average wages were closer to the minimum wage.

We last analyse the impact of labor NGO activism on the wage gap in non-compliant firms by size. Small firms are defined as those with under 50 employees, medium firms those with 50 to 250 employees, and large firms those with over 250 employees. We then estimate Equation 2 separately by firm size. All regressions control for the firm-level variables profit, growthK, perdompriv, perPUBLIC and nbskill, as well as interacted Province and year fixed effects. Table 7 shows the results. The dummy variable NGO is negative and significant for small firms, and insignificant for medium and large firms. The effect of labor NGO activism is then concentrated in small firms. This is plausible: as noted above, small Indonesian firms were more likely to violate minimum-wage standards since they were too small to organize trade unions and

\footnotetext{
${ }^{35}$ For more details on the relation between the demand for skilled workers and wage determination for unskilled workers within a

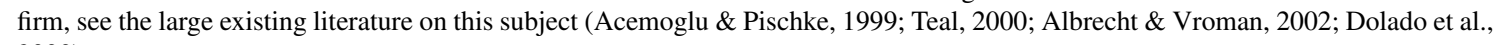
2000 .
} 
were monitored less often by labor inspectors. NGO activities were then particularly important for these firms.

\section{Robustness checks}

\subsection{Reputation concerns}

During the 1990s, local Indonesian labor NGOs built an international network with Northern NGOs focused on working conditions in developing countries and acting against well-known multinational firm brands. Civil-society activists launched a substantial campaign in Indonesia regarding working conditions in exporting firms in the textile-footwear-apparel (TFA) sector. As shown by Harrison \& Scorse (2010), Indonesian foreign and exporting firms increased the average wage following this campaign for reputational reasons. More specifically, these TFA firms increased their wages largely by greater compliance with minimum wages. However, as previously mentioned, over half of Indonesian firms did not comply with the new minimum wages. While we focus on these non-compliant firms, with average wages below the minimum, the effect of labor NGOs may have been concentrated on exporting firms in TFA sector, where the reputation of the firm mattered more.

As a first robustness check, we estimate Equation 2 including as a control variable the sector dummy $T F A$ for the firm being in the textile-footwear-apparel sector. We then exclude exporting and foreign firms from the sample. Table 8 shows the results: column (1) excludes foreign firms, column (2) excludes exporting firms, and column (3) includes the dummy for firms in the textile-footwear-apparel sector. In all specifications, the sign and size of the estimated coefficient on our variable of interest (NGO) does not change. This suggests that the threat of losing GSP privileges is different from that of civil-society campaigns against well-known multinational brands. The former can damage the country's reputation and eventually affect working conditions even outside the export sector, while the effects of the latter are concentrated on exporting firms in particular sectors.

Finally, as an additional robustness check, column (4) of Table 8 excludes the Province of Jakarta, as this was where the footwear sector was largely concentrated in the period under analysis (Deichmann et al., 2005). In addition, labor NGOs in Jakarta may be better able to develop networks with international NGOs. The sign and size of the NGO coefficient remains unchanged.

\subsection{Placebo tests}

We carry out two placebo tests as additional robustness checks. We first construct a "new" time shock, re-estimating Equation (1) and replacing the time dummy $T$ with a time dummy $T p$ equal to 1 in 1993 
and 0 pre-1993. We then interact this new time dummy with the NGO dummy. Our dependent variable is the logarithm of firm-level average wages. We consider only non-compliant firms, and run a difference-indifference estimation. As above we include firm-level controls: profit, growthK, perPUBLIC, perdompriv and nbskill. All regressions include firm fixed effects and interactions between the Province and year fixed effects. Table 9 shows the results: the coefficient on the $T p * N G O)$ interaction is insignificant, so that our previous effect is particular to the period after 1994 when the US GSP revision came to an end. We in addition re-estimate Equation (2) for non-compliant firms, considering only the period before the US GSP revision as a placebo: the NGO dummy is insignificant in the results in Table 10

In the second Placebo test, we replace the labor NGO dummy by other humanitarian NGOs that are specialized in health and gender issues, respectively. The main argument here is that labor NGOs are different from other human-rights NGOs, as they carry out activities that are traditionally undertaken by Trade Unions. We therefore expect the impact on the wage gap to be limited to Districts where labor NGOs were active. Information on the location of other humanitarian Indonesian NGOs is publicly available in the dataset on the website of SMERU ${ }^{36}$ Column (1) of Table 11 re-estimates Equation 23 replacing the $N G O$ dummy by the $N G O H$ dummy (for Districts with NGOs working on health issues); analogously, in column (2) NGOW is a dummy for Districts with NGOs working on gender issues. In both specifications, there is no significant difference in the wage gap between firms in Districts with and without humanitarian NGOs. This confirms that NGOs are mission-oriented organizations, and that our results seem to capture the effects of NGOs working exclusively on labor issues ${ }^{37}$

\subsection{Geographical determinants}

In this section, we discuss the geographical distribution of labor NGOs in order to address potential endogeneity in their location. We first describe the geographical and historical determinants of industrial development in Indonesia, and then turn to additional robustness checks to address other District-level economic factors as well as the presence of labor unrest during 1990s that could lie behind our results.

The geographical distribution of Indonesian labor NGOs may reflect the concentration of industry in certain Districts. During the 1980s ${ }^{38}$ Indonesian industrial activity was concentrated in the major metropolitan areas in Java and North Sumatra (Henderson \& Kuncoro, 1996) ${ }^{39}$ Figure 3 illustrates the geographical distribution of industrial sectors in colonial Indonesia (1848-1942). Lukman \& Marwoto (2017) show that

\footnotetext{
${ }^{36}$ The SMERU NGO link is http://www.smeru.or.id/en/content/ngo-database; accessed on March 10th 2019. We consider NGOs specialized in health issues, and in women and gender issues.

37 Besley \& Ghatak (2005) provide a theoretical explanation of the existence of mission-oriented organizations.

${ }^{38}$ The first labor NGO was created in 1973, while the majority developed during the 1980s (Ford 2009).

${ }^{39}$ According to Henderson \& Kuncoro (1996), industrial centralization in Indonesia, close to large metropolitan areas, is due to proximity to the capital and bureaucratic center, as well as for historical reasons. This determines the presence of corporate firms that attracts, in turn, smaller firms to take advantage of positive externalities and better information, due to the larger industrial concentration in a given sector. This trend had already started with the first phase of Indonesian industrialization during the 1970s, and strengthened after trade liberalization in 1983.
} 
companies operating in different sectors in that period were spread throughout the Netherlands Indies territory, especially in Java Island ${ }^{40}$ Interestingly, Dell \& Olken (2020) show that areas in the surroundings of sugar factories, established by the Dutch in the mid-19th century in Java Island, are today more industrialized than are nearby counterfactual locations. The Dutch divided Colonial Indonesia into a number of residencies, which were the colonial administrative centres. The capitals of these colonial residencies remain the largest cities today (Dell \& Olken 2020). Figure 4 shows the current location of Industrial Areas in Indonesia. The industrial concentration in major metropolitan areas in Indonesia has obviously persisted over time. Labor NGOs were located in some major metropolitan areas but, more importantly for us, not all of them ${ }^{41}$ A number of other factors may help explain the geographical distribution of Indonesian labor NGOs across major metropolitan areas, namely religion, ethnicity and the presence of Universities ${ }^{42}$ Further, in the main regression we include time-varying variables at the District level as proxies for District economic activity, namely the District share of firms within the Province (sharefirmd), the District share of exporting firms over the number of firms (shareEXPfirmd), the District share of foreign firms over the number of firms (shareFORfirmd), and average District firm profit (avprofitd). Table 12 lists the results. Columns (1) and (2) refer to Equation 1. Column (3) adds sharefirmd, shareEXPfirmd, shareFORfirmd and avprofitd. The coefficient on our variable of interest, $T^{*} N G O$, remains positive and very significant. Columns (1) and (2) of of Table 13 refer to Equation 2, and column (3) adds sharefirmd, shareEXPfirmd, shareFORfirmd and avprofitd. The estimated NGO coefficient remains negative and very significant.

One additional endogeneity concern is that the presence of labor NGOs be related to the probability that a firm be non-compliant (with average wage below the minimum wage). To exclude this possibility, we run the following logit regression:

$$
\text { noncompliant }_{i d t}=\alpha+\beta_{1} N G O_{d}+\beta_{2} N G O * T_{d t}+\beta_{3} X_{i t}+\eta_{i}+\eta_{t}+\epsilon_{i d t}
$$

where the dependent variable noncompliant ${ }_{i d t}$ is a dummy for the average wage of firm $(i)$ in District $(d)$ and year $(t)$ being below the minimum wage. We interact the $N G O$ dummy with a dummy variable $T$ that is 1 after 1994. We include, as above, controls at the firm level (the number of unskilled workers, profit, and the rise in the capital stock). Last, $\eta_{i}$ and $\eta_{t}$ are fixed effects at the firm and year levels, respectively. The results appear in Table 14. There is no significant effect for firms in Districts with labor NGOs, even

\footnotetext{
40 Lukman \& Marwoto (2017) analyze historical commercial papers to reconstruct the early industrialization era in Indonesia. In Figure 3 districts are indicated by their name, while the numbers under the district names identify the particular companies located there.

${ }^{41}$ See the location of labor NGOs in Table 17.

${ }^{42}$ As indicated in the list of labor NGOs in Table 17, Christian Labor NGOs are located in Jakarta. Almost 10 percent of the population in Jakarta is Christian, the majority from the Chinese Ethnic Group, historically concentrated in the Jakarta metropolitan area (Suryadinata et al. 2003). Some labor NGOs were established by student activists, which is obviously linked to the presence of Universities in that area.
} 
in the period after the large rise in the minimum wage in Indonesian provinces. We can also see that the probability of paying below the minimum wage increased significantly from 1994 onwards.

There was a substantial increase in labor unrest in Indonesia during the 1980s and 1990s. Strikes were concentrated in some Districts with major metropolitan areas in Java and North Sumatra, and in certain sectors ${ }^{43}$ According to Kammen (1997), the geographical distribution of strikes reflects the concentration of sectors faced with international competition in specific areas, for historical or geographical reasons (e.g. the presence of harbors, industrial areas, or natural resources). One of the main factors explaining the rise in strikes in the first part of 1994 was the approach in mid-March of Lebaran, "the most important Muslim holiday in Indonesia that marks the end of the fasting month, Ramadan"44 In early 1994, the bonus, corresponding to almost one month's salary, was not required by Law. Some companies did not pay, citing financial factors such as the rise in the minimum wage. There was also increasing worker awareness of their labor rights in Indonesian law, "thanks to the efforts of non-governmental organizations (NGOs) and unrestricted reporting on labor issues in the Indonesian press" Although non-compliance with the minimum wage was not the main cause of the strikes, it could have had an indirect impact on wages as the violence of the labor unrest attracted international attention. Following Rama (1996), we hypothesize that this effect was larger where labor NGOs were active, via their links to international NGOs and their capacity to contact foreign medias.

Importantly for identification purposes, the strikes took place in Districts both with and without labor NGOs. We rely on the detailed list of the location (at the District level) and year of strikes in Kammen (1997). We construct a dummy variable "strike" for the firm being located in a District with at least one strike. We re-estimate Equation 2 including the strike variable. Table 15 shows the results. Column (1) adds the variables sharefirmd, shareEXPfirmd, shareFORfirmd and avprofitd, column (2) strike, and column (3) interacted sector and year fixed effects to control for any sector-specific shock. Sectors are at the 5-digit level, as strikes were concentrated in certain specific sub-sectors (Kammen, 1997). The coefficient on our main variable of interest $N G O$ remains negative and significant. In Table 16 we restrict the analysis to Districts where strikes took place during 1994-1996, to see whether there is any difference in the wage gap between firms in Districts with and without labor NGOs. In column 1 we re-estimate Equation 2 and then add control variables for District-level industrial activity in column 2 and sector-year fixed effects in column 3. The coefficient of our main variable of interest, NGO, remains negative and significant, and even becomes somewhat larger. Our identified effect of labor NGOs on the wage gap is thus not concentrated

\footnotetext{
${ }^{43}$ The origin of this unrest lay in Indonesian industrial development, especially in the transition from import-substitution to exportpromotion (Kammen 1997), with the co-existence of State-protected sectors, a heritage of the first wave of Indonesian industrialization (late 1960s-1970s) and new dynamic export sectors (with both foreign and domestic firms). The State did not adapt industrial relations to the new Indonesian industrial structure. In unprotected sectors, firms under pressure from international competition reduced the cost of productions by cutting wages.

${ }^{44}$ Human Rights Watch/Asia, Vol.6, No.4, May 1994.

${ }^{45}$ Human Rights Watch/Asia, Vol.6, No.4, May 1994.
} 
in Districts and sectors that experienced labor unrest. Additionally, the effect is even larger in firms in Districts with labor NGOs. This suggests that the organization of strikes, a channel that did indeed lead to better labor conditions in Indonesia over this period, required financial, logistic and legal support in order to be effective in the "bargaining" process with firms. In the absence of independent trade unions, this role was mainly performed by labor NGOs.

\section{Conclusion}

This paper has focused on Manufacturing firms in Indonesia, and addressed the impact of the US GSP revision and labor NGO activism on the wage gap, the difference between the minimum wage and firmlevel average wages. We exploit geographical variation in labor NGO activism, and consider the deadline of the third US GSP revision (at the beginning of 1994) as an external shock. We first run a differencein-difference regression to estimate the impact of labor NGO activism on average wages in non-compliant firms after the US GSP revision. In a second step, we estimate a panel regression to measure the wage gap in Districts where labor NGOs were active and in the period following the US GSP revision.

We show that non-compliant firms in Districts with labor NGOs paid higher average wages than those in Districts without labor NGOs after the US GSP revision. Moreover, the wage gap fell in Districts with labor NGOs after the GSP revision.

Our argument is that the minimum wage can be a reference point in wage bargaining in developing countries, for workers earning below the minimum wage. Labor NGOs played a role in this bargaining process in Indonesia, as the information they provided to workers on labor rights and Laws reduced the asymmetry of information between employers and employees. The attention paid by the international community, with the US GSP revision, to labor conditions made the activities of labor NGOs more effective. The GSP leverage allowed labor NGOs to act more efficiently by putting Indonesian working conditions under the international spotlight.

Our work here opens more avenues for research, as it highlights the complexity of labor-market relations in developing countries that have progressively moved towards more worker-friendly institutions. It also highlights the potential impact of commercial policies in these countries beyond the sectors that are directly exposed to trade. We here illustrated how local labor activists can help put into effect GSP leverage on working and human-rights compliance in Indonesia. It would be useful to extend this analysis to other countries that have experienced GSP revisions. 


\section{References}

Acemoglu, D. \& Pischke, J.-S. (1999). Beyond Becker: Training in Imperfect Labour Markets. Economic Journal, 109(453), 112-142.

Albrecht, J. \& Vroman, S. (2002). A Matching Model with Endogenous Skill Requirements. International Economic Review, 43(1), 283-305.

Baldwin, R. E. \& Murray, T. (1977). MFN tariff reductions and developing country trade benefits under the gsp. Economic Journal, 87(345), 30-46.

Besley, T. \& Ghatak, M. (2005). Competition and incentives with motivated agents. American Economic Review, 95(3), 616-636.

Bhorat, H., Kanbur, R., \& Stanwix, B. (2015). Partial minimum wage compliance. IZA Journal of Labor and Development, 4(1), 1-20.

Brenton, P. \& Manchin, M. (2002). Making EU Trade Agreements Work: The Role of Rules of Origin. International Trade 0203003, EconWPA.

Brown, D. K. (1988). Trade preferences for developing countries: A survey of results. The Journal of Development Studies, 24(3), 335-363.

chi Chan, C. K. (2013). Community-based organizations for migrant workers' rights: The emergence of labour NGOs in China. Community Development Journal, 48 N 1, 6-22.

Crinis, V. (2008). Malaysia: Women, labour activism and unions. in K. Broadbent and M. Ford,. Women and Labour Organizing in Asia: Diversity, Autonomy and Activism, London:Routledge.

Deichmann, U., Kaiser, K., Lall, S. V., \& Shalizi, Z. (2005). Agglomeration, transport, and regional development in Indonesia. Policy Research Working Paper Series 3477, The World Bank.

Dell, M. \& Olken, B. A. (2020). The Development Effects of the Extractive Colonial Economy: The Dutch Cultivation System in Java. Review of Economic Studies, 87(1), 164-203.

Dolado, J. J., Felgueroso, F., \& Jimeno, J. F. (2000). Youth labour markets in Spain: Education, training, and crowding-out. European Economic Review, 44(4-6), 943-956.

Elliott, K. (1998). Preferences for workers? Worker rights and the US generalized system of preferences. Speech prepared for the faculty spring conference. Calvin College, Grand Rapids, Mich.,, May 28-30.

Falk, A., Fehr, E., \& Zehnder, C. (2006). Fairness perceptions and reservation wages: the behavioral effects of minimum wage laws. Quarterly Journal of Economics, 121(4), 1347-1381. 
Ford, M. (2006). Labour NGOs: An Alternative Form of Labour Organizing in Indonesia, 1991-1998. Asia Pacific Business Review, 12(2), 175-191.

Ford, M. (2009). Workers and Intellectuals. NGOs, Trade Unions and the Indonesian Labour Movement. Southeast Asia Publications Series.

Gamberoni, E. (2007). Do unilateral trade preferences help export diversification? An investigation of the impact of European unilateral trade preferences on the extensive and intensive margin of trade. IHEID Working Papers 17-2007, Economics Section, The Graduate Institute of International Studies.

Gil-Pareja, S., Llorca-Vivero, R., \& Martínez-Serrano, J. A. (2014). Do nonreciprocal preferential trade agreements increase beneficiaries' exports? Journal of Development Economics, 107, 291-304.

Glasius, M. (1999). Foreign Policy on Human Rights. Its Influence on Indonesia under Soeharto. Intersentia Antwerpen.

Goraus-Tanska, K. \& Lewandowski, P. (2019). Minimum wage violation in Central and Eastern Europe. International Labour Review, 158(2), 297-336.

Gough, R., Holland, P., \& Teicher, J. (2013). Employment relations in the Asia-Pacific region. In Employment Relations in the Asia-Pacific Region (pp. 7-18). Routledge.

Ham, A. (2018). The consequences of legal minimum wages in Honduras. World Development, 102, 135-157.

Harrison, A. \& Scorse, J. (2003). Globalization's impact on compliance with labor standards. MPRA Paper 36450, University Library of Munich, Germany.

Harrison, A. \& Scorse, J. (2010). Multinationals and anti-sweatshop activism. American Economic Review, 100:1, 247-273.

Henderson, J. V. \& Kuncoro, A. (1996). Industrial centralization in indonesia. The World Bank Economic Review, 10(3), 513-540.

Kammen, D. (1997). A time to strike: industrial strikes and changing class relations in New Order Indonesia. PhD thesis, Ithaca: Cornell University.

Lukman, A. \& Marwoto, I. (2017). The beginnings of industrialization in Indonesia: Identification of the first industrial companies through commercial papers. Working paper, University of Indonesia.

Özden, c. \& Reinhardt, E. (2005). The perversity of preferences: GSP and developing country trade policies, 1976-2000. Journal of Development Economics, 78(1), 1-21. 
Rama, M. (1996). The consequences of doubling the minimum wage: The case of Indonesia. Policy Research Working Paper Series 1643, The World Bank.

Sivananthiran, A. (2009). Promoting decent work in export promotion zones in Indonesia. Technical report, International Labor Organization.

Suryadinata, L., Arifin, E., \& Ananta, A. (2003). Indonesia's Population: Ethnicity and Religion in a Changing Political Landscape. Institute of Southeast Asian Studies.

Teal, F. (2000). Real wages and the demand for skilled and unskilled male labour in Ghana's manufacturing sector: 1991-1995. Journal of Development Economics, 61(2), 447-461.

Wang, X. (2012). When workers do not know: The behavioral effects of minimum wage laws revisited. Journal of Economic Psychology, 33(5), 951 - 962. 
Figure 1: Minimum wages and average wages over time

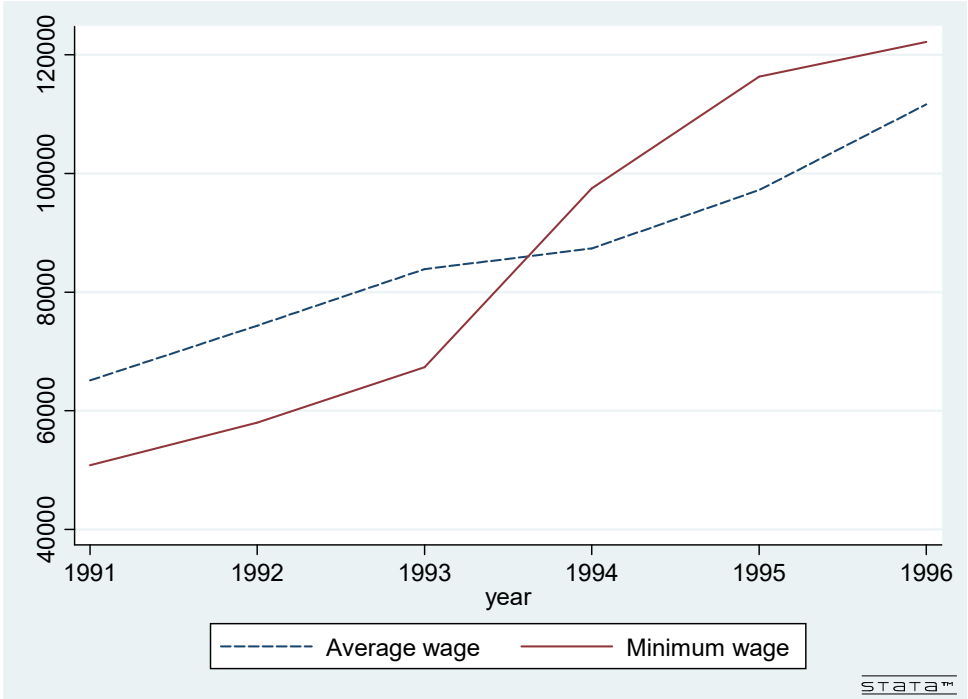


Figure 2: Wage gap with year, Province and sector fixed effects, non-compliant firms

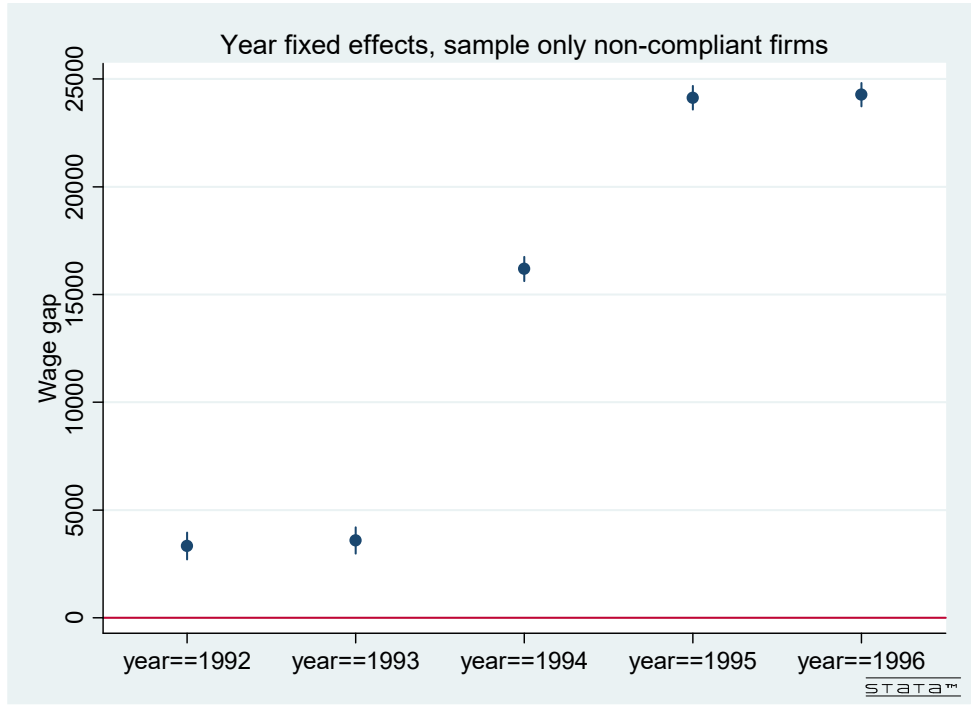


Figure 3: The distribution of companies and industrial sectors in colonial Indonesia 1848 to 1942

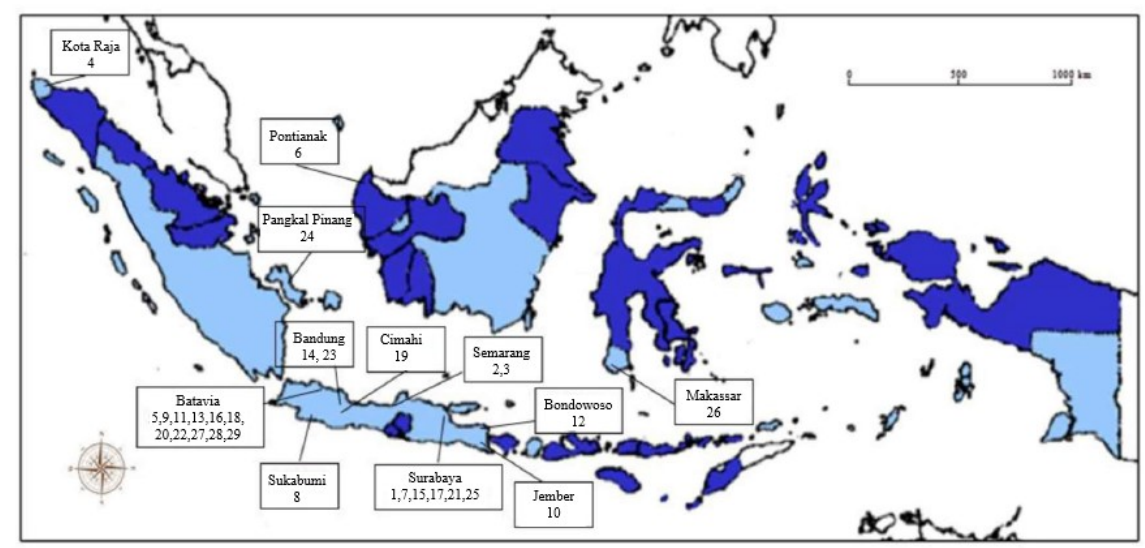

LEGENDS:

Netherlands Indies territory

Autonomous regions

\footnotetext{
2017)

${ }^{45}$ Source: Fig. 3 "The distribution of companies and industrial sectors in colonial Indonesia 1848 to 1942", in (Lukman \& Marwoto
} 
Figure 4: Current Industrial Areas in Indonesia

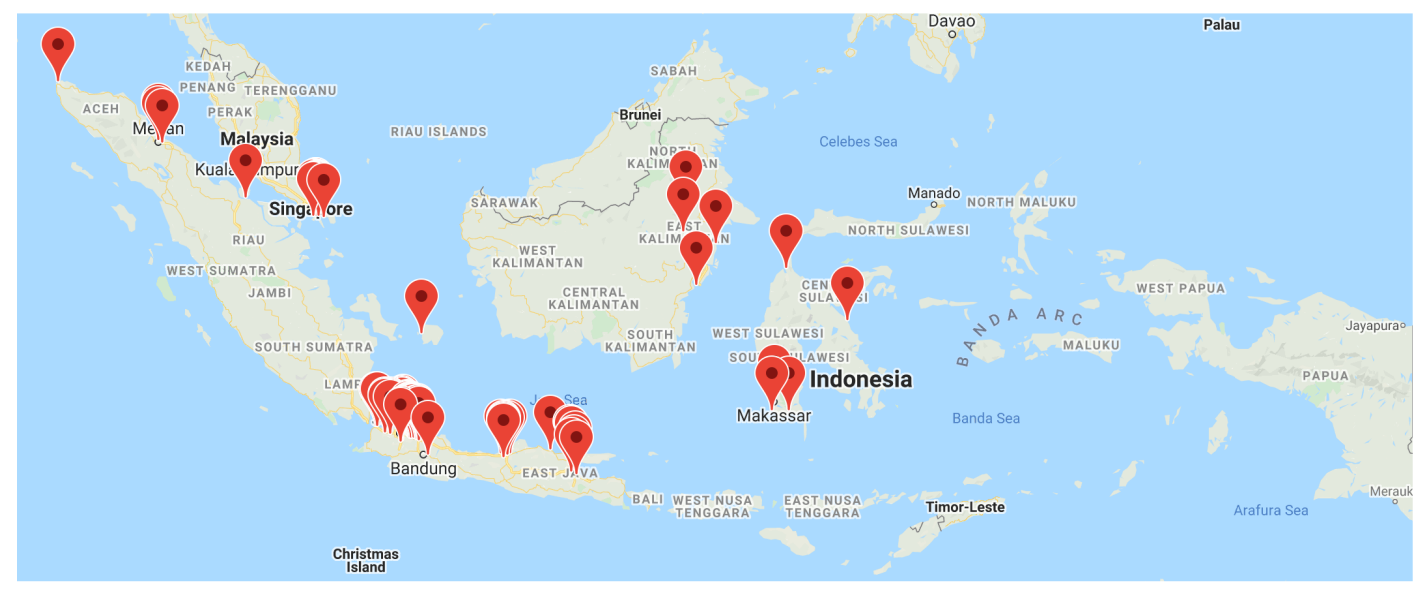

${ }^{45}$ Source: EU-Indonesia Business Network http://www. industrialestateindonesia.com/data-estate Accessed March 15,2021 
Table 1: Firm-level average wages and the mean minimum wage per year

\begin{tabular}{rrrrr}
\hline Year & Firm average wage & Mean Minimum wage & Wage gap & Wage ratio \\
\hline 1991 & 65119.61 & 50792.08 & -13084.51 & 1.27 \\
1992 & 74346.09 & 58006.17 & -15576.66 & 1.30 \\
1993 & 83869.47 & 67322.60 & -15070.00 & 1.25 \\
\hline 1994 & 87361.43 & 97504.21 & 9288.27 & 0.89 \\
1995 & 97193.26 & 116348.40 & 17638.26 & 0.83 \\
1996 & 111652.84 & 122187.36 & 9891.57 & 0.91 \\
Total & 88300.87 & 88502.25 & 176.34 & 1.06 \\
\hline
\end{tabular}

Average wage is the total wage at the firm level divided by the number of workers. Minimum wage is the annual mean minimum wage at the Province level. The wage gap is the minimum wage minus average wages. The wage ratio is average wages over the minimum wage. 
Table 2: Non-compliant firms by year

\begin{tabular}{lrrr}
\hline Year & Number of firms & Non-compliant firms & Share non-compliant \\
\hline 1991 & 16494 & 8070 & 0.49 \\
1992 & 17648 & 8184 & 0.46 \\
1993 & 18163 & 8427 & 0.46 \\
1994 & 19017 & 12370 & 0.65 \\
1995 & 21551 & 14831 & 0.69 \\
1996 & 22997 & 14661 & 0.64 \\
Total & 19576 & 11887 & 0.59 \\
\hline
\end{tabular}


Table 3: Comparison of the Treatment and Control Groups Prior to Treatment: All firms (1991-1993)

\begin{tabular}{lrrrr}
\hline NGO & Wage gap & No. workers & Wage ratio & Average wage \\
\hline (1) Control & -16755.4 & 198.57 & 1.31 & 72618.1 \\
& $(3690.24)$ & $(4.32)$ & $(.067)$ & $(3690.5)$ \\
& & & & \\
(2) Treatment & -25288.2 & 173.15 & 1.47 & 83186.4 \\
& $(7093.559)$ & $(.14)$ & $(.199)$ & $(4321.2)$ \\
& & & & \\
(3) Difference & 8532.76 & 25.41 & -.160 & -10568.3 \\
& $(8382.94)$ & $(9.66)$ & $(.155)$ & $(8383.70)$ \\
(4) t-test diff & & & & \\
\hline
\end{tabular}

Average wage is the total wage at the firm level divided by the number of workers. Wage gap is the minimum wage minus average wages. The wage ratio is average wages over the minimum wage. No. workers is the total number of unskilled workers at the firm level. Standard errors are in parentheses. *, ** and *** indicate that the difference in means are statistically significant at the $0.10,0.05$ and 0.01 levels respectively. All values are in real Rupiahs. 
Table 4: Comparison of the Treatment and Control Groups Post-Treatment: All firms (1994-1996)

\begin{tabular}{lrrrr}
\hline NGO & Wage gap & No. workers & Wage ratio & Average wage \\
\hline (1) Control & 15564.22 & 203.71 & .85 & 96468.56 \\
& $(416.96)$ & $(3.91)$ & $(.003)$ & $(430.07)$ \\
& & & & \\
(2) Treatment & 3128.45 & 186.09 & .973 & 107690.9 \\
& $(1563.44)$ & $(8.907)$ & $(.012)$ & $(1578.35)$ \\
(3) Difference & 12435.77 & 17.61 & -.118 & -11222.38 \\
& $(1164.64)$ & $(9.61)$ & $(.009)$ & $(1192.09)$ \\
& & & & \\
(4) t-test diff & $10.67 * * *$ & $1.83^{*}$ & $-12.26 * * *$ & $-9.41 * * *$ \\
\hline
\end{tabular}

Average wage is the total wage at the firm level divided by the number of workers. Wage gap is the minimum wage minus average wages. The wage ratio is average wages over the minimum wage. No. workers is the total number of unskilled workers at the firm level. Standard errors are in parentheses. *,** and *** indicate that the difference in means are statistically significant at the $0.10,0.05$ and 0.01 levels respectively. All values are in real Rupiahs. 
Table 5: Difference-in-Difference Estimation. Non-compliant and compliant firms

\begin{tabular}{|c|c|c|c|c|}
\hline \multicolumn{5}{|c|}{ Dependent variable: log-wage } \\
\hline & Non-compliant (1) & Non-compliant (2) & Compliant(1) & Compliant (2) \\
\hline & Coef./se & Coef./se & Coef./se & Coef./se \\
\hline \multirow[t]{2}{*}{ NGO } & -0.044 & -0.044 & -0.018 & -0.018 \\
\hline & $(0.04)$ & $(0.04)$ & $(0.04)$ & $(0.04)$ \\
\hline \multirow[t]{2}{*}{ T*NGO } & $0.050 * *$ & $0.050 * *$ & -0.003 & -0.003 \\
\hline & $(0.02)$ & $(0.02)$ & $(0.01)$ & $(0.01)$ \\
\hline \multirow[t]{2}{*}{ Profit } & -0.117 & -0.119 & 0.005 & 0.003 \\
\hline & $(0.37)$ & $(0.37)$ & $(0.08)$ & $(0.08)$ \\
\hline \multirow[t]{2}{*}{ GrowthK } & 0.045 & 0.045 & -0.081 & -0.082 \\
\hline & $(0.29)$ & $(0.29)$ & $(0.12)$ & $(0.12)$ \\
\hline \multirow[t]{2}{*}{ Nbskill } & $-0.051 * * *$ & $-0.051 * * *$ & $-0.022 * * *$ & $-0.022 * * *$ \\
\hline & $(0.01)$ & $(0.01)$ & $(0.01)$ & $(0.01)$ \\
\hline \multirow[t]{2}{*}{ Perdompriv } & & 0.000 & & -0.004 \\
\hline & & $(0.00)$ & & $(0.00)$ \\
\hline \multirow[t]{2}{*}{ PerPUBLIC } & & 0.000 & & 0.000 \\
\hline & & $(0.00)$ & & $(0.00)$ \\
\hline $\mathrm{R}^{2}$ & 0.421 & 0.421 & 0.439 & 0.439 \\
\hline $\mathrm{N}$ & 66540 & 66540 & 37757 & 37757 \\
\hline Firm fixed effects & Yes & Yes & Yes & Yes \\
\hline Year*Province fixed effects & Yes & Yes & Yes & Yes \\
\hline
\end{tabular}


Table 6: Panel Estimation, Post-1994. Noncompliant firms

Dependent variable: log-wage gap.

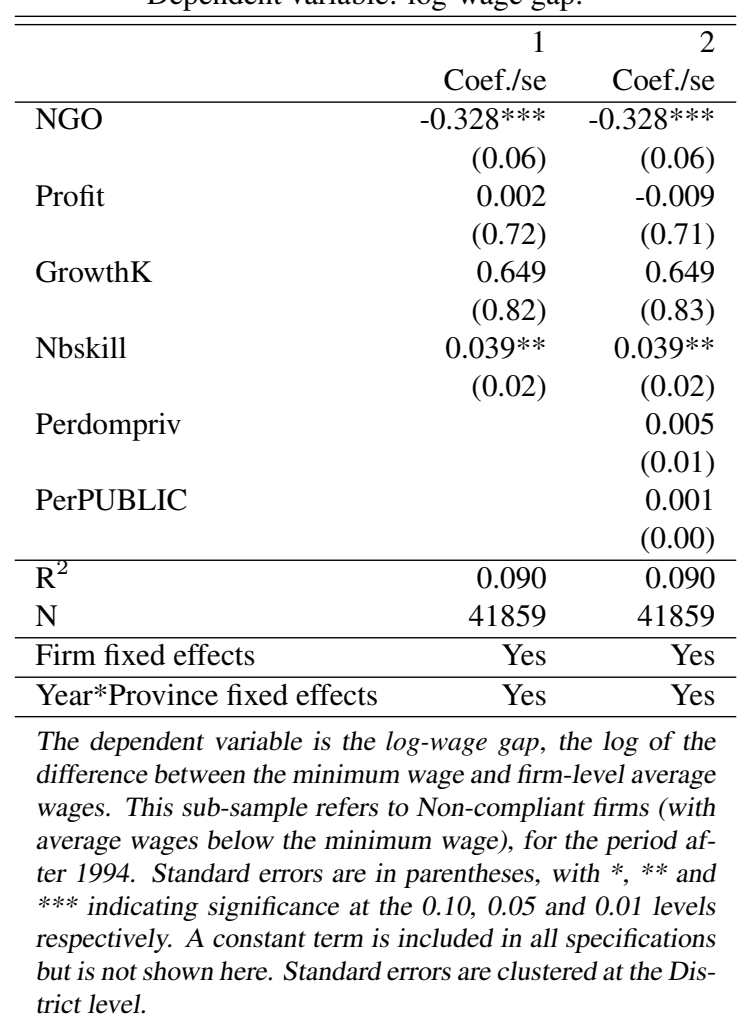


Table 7: Panel Estimation, Post-1994. Non-compliant firms by size

Dependent variable: log-wage gap

\begin{tabular}{lrrr}
\hline \hline & $\begin{array}{r}\text { Small } \\
\text { Coef./se }\end{array}$ & $\begin{array}{r}\text { Medium } \\
\text { Coef./se }\end{array}$ & $\begin{array}{r}\text { Large } \\
\text { Coef./se }\end{array}$ \\
\hline NGO & $-0.565^{* * *}$ & -0.117 & 0.013 \\
& $(0.14)$ & $(0.07)$ & $(0.05)$ \\
Profit & $-213.361^{* * *}$ & $-10.522^{* *}$ & 0.174 \\
& $(52.54)$ & $(5.20)$ & $(0.61)$ \\
GrowthK & -7.178 & 0.069 & 5.797 \\
& $(34.98)$ & $(0.30)$ & $(5.05)$ \\
Nbskill & $3.155^{* * *}$ & $0.490 * * *$ & $0.031^{* *}$ \\
& $(0.38)$ & $(0.08)$ & $(0.01)$ \\
Perdompriv & 0.015 & -0.004 & 0.003 \\
& $(0.02)$ & $(0.02)$ & $(0.02)$ \\
PerPUBLIC & 0.002 & 0.001 & 0.000 \\
& $(0.00)$ & $(0.00)$ & $(0.00)$ \\
\hline $\mathrm{R}^{2}$ & 0.127 & 0.089 & 0.124 \\
$\mathrm{~N}$ & 23973 & 13068 & 4690 \\
\hline Firm fixed effects & Yes & Yes & Yes \\
\hline Year*Province fixed effects & Yes & Yes & Yes \\
\hline
\end{tabular}

The dependent variable is the log-wage gap, defined as the log of the difference between the minimum wage and firm-level average wages. Small firms are those with fewer than 50 employees, medium firms those with 50250 employees, and large firms those with over 250 employees. This subsample refers to Non-compliant firms (with average wages below the minimum wage), for the period after 1994.

Standard errors are in parentheses, with *, ** and *** indicating significance at the $0.10,0.05$ and 0.01 levels respectively. A constant term is included in all specifications but is not shown here. Standard errors are clustered at the District level. 
Table 8: Robustness check - TFA sector: Panel Estimation, Post-1994. Noncompliant firms

\begin{tabular}{|c|c|c|c|c|}
\hline \multicolumn{5}{|c|}{ Dependent variable: log-wage gap } \\
\hline & 1 & 2 & 3 & $\overline{4}$ \\
\hline & Coef./se & Coef./se & Coef./se & Coef./se \\
\hline \multirow{2}{*}{ NGO } & $-0.333 * * *$ & $-0.351 * * *$ & $-0.328 * * *$ & $-0.328 * * *$ \\
\hline & $(0.05)$ & $(0.07)$ & $(0.06)$ & $(0.06)$ \\
\hline \multirow[t]{2}{*}{ Profit } & 0.040 & $-6.150 * * *$ & -0.009 & -0.034 \\
\hline & $(0.67)$ & $(1.98)$ & $(0.71)$ & $(0.71)$ \\
\hline \multirow[t]{2}{*}{ GrowthK } & 0.234 & 0.630 & 0.648 & 0.608 \\
\hline & $(0.67)$ & $(0.71)$ & $(0.83)$ & $(0.81)$ \\
\hline \multirow[t]{2}{*}{ Nbskill } & $0.036^{* *}$ & $0.128 * * *$ & $0.039 * *$ & $0.037 * *$ \\
\hline & $(0.01)$ & $(0.03)$ & $(0.02)$ & $(0.01)$ \\
\hline \multirow[t]{2}{*}{ Perdompriv } & 0.017 & 0.015 & 0.005 & 0.009 \\
\hline & $(0.44)$ & $(0.01)$ & $(0.01)$ & $(0.01)$ \\
\hline \multirow[t]{2}{*}{ PerPUBLIC } & 0.002 & $0.002 * *$ & 0.001 & 0.002 \\
\hline & $(0.04)$ & $(0.00)$ & $(0.00)$ & $(0.00)$ \\
\hline \multirow{2}{*}{ TFA } & & & -0.078 & \\
\hline & & & $(0.15)$ & \\
\hline $\mathrm{R}^{2}$ & 0.091 & 0.101 & 0.090 & 0.087 \\
\hline $\mathrm{N}$ & 40636 & 36017 & 41859 & 39598 \\
\hline Firm fixed effects & Yes & Yes & Yes & Yes \\
\hline Year*Province fixed effects & Yes & Yes & Yes & Yes \\
\hline
\end{tabular}

The dependent variable is the log-wage gap, defined as the log of the difference between the minimum wage and firm-level average wages. This sub-sample refers to Non-compliant firms (with average wages below the minimum wage), for the period after 1994.

Column (1) excludes foreign firms, column (2) excludes exporting firms, column (3) includes the TFA dummy for firms in the textile-footwear-apparel sector, and column (4) excludes the Province of Jakarta.

Standard errors are in parentheses, with *,** and *** indicating significance at the 0.10 , 0.05 and 0.01 levels respectively. A constant term is included in all specifications but is not shown here. Standard errors are clustered at the District level. 
Table 9: Placebo test: Difference-in-Difference Estimation, 1991-1993. Non-compliant firms

\begin{tabular}{lrrr}
\multicolumn{4}{c}{ Dependent variable: log-wage } \\
\hline \hline NGO & 1 & 2 & 3 \\
& Coef./se & Coef./se & Coef./se \\
\hline \multirow{2}{*}{ Tp*NGO } & 0.041 & 0.041 & 0.041 \\
& $(0.10)$ & $(0.10)$ & $(0.10)$ \\
Profit & 0.005 & 0.005 & 0.005 \\
& $(0.03)$ & $(0.03)$ & $(0.03)$ \\
GrowthK & 1.348 & 1.363 & 1.365 \\
& $(1.70)$ & $(1.70)$ & $(1.70)$ \\
Nbskill & $-0.426^{* *}$ & $-0.422^{* *}$ & $-0.422^{* *}$ \\
& $(0.20)$ & $(0.20)$ & $(0.20)$ \\
Perdompriv & $-0.054^{* * *}$ & $-0.054^{* * *}$ & $-0.054^{* * *}$ \\
& $(0.01)$ & $(0.01)$ & $(0.01)$ \\
PerPUBLIC & & 0.002 & 0.002 \\
& & $(0.01)$ & $(0.01)$ \\
TFA & & 0.000 & 0.000 \\
& & $(0.00)$ & $(0.00)$ \\
$\mathrm{R}^{2}$ & & & 0.028 \\
$\mathrm{~N}$ & & & $(0.07)$ \\
\hline Firm fixed effects & & & \\
\hline Year*Province fixed effects & Yes & Yes & Yes \\
\hline
\end{tabular}

The dependent variable is the log-wage, defined as the log average wage at the firm level for unskilled workers. Standard errors are in parentheses, with $*, * *$ and *** indicating significance at the $0.10,0.05$ and 0.01 levels respectively. A constant term is included in all specifications but is not shown here. Standard errors are clustered at the District level. 
Table 10: Placebo test: Panel Estimation, 1991-1993. Noncompliant firms

\begin{tabular}{|c|c|c|c|}
\hline \multicolumn{4}{|c|}{ Dependent variable: log-wage gap } \\
\hline & 1 & 2 & 3 \\
\hline & Coef./se & Coef./se & Coef./se \\
\hline \multirow[t]{2}{*}{ NGO } & -0.295 & -0.295 & -0.295 \\
\hline & $(0.21)$ & $(0.21)$ & $(0.21)$ \\
\hline \multirow[t]{2}{*}{ Profit } & -0.902 & -0.857 & -0.860 \\
\hline & $(2.92)$ & $(2.91)$ & $(2.91)$ \\
\hline \multirow{2}{*}{ GrowthK } & 1.302 & $1.314^{*}$ & $1.313^{*}$ \\
\hline & $(0.79)$ & $(0.79)$ & $(0.79)$ \\
\hline \multirow[t]{2}{*}{ Nbskill } & $0.074 * * *$ & $0.074 * * *$ & $0.074 * * *$ \\
\hline & $(0.01)$ & $(0.01)$ & $(0.01)$ \\
\hline \multirow[t]{2}{*}{ Perdompriv } & & 0.007 & 0.007 \\
\hline & & $(0.02)$ & $(0.02)$ \\
\hline \multirow[t]{2}{*}{ PerPUBLIC } & & 0.001 & 0.001 \\
\hline & & $(0.00)$ & $(0.00)$ \\
\hline \multirow[t]{2}{*}{ TFA } & & & -0.034 \\
\hline & & & $(0.20)$ \\
\hline $\mathrm{R}^{2}$ & 0.152 & 0.152 & 0.152 \\
\hline $\mathrm{N}$ & 24681 & 24681 & 24681 \\
\hline Firm fixed effects & Yes & Yes & Yes \\
\hline Year*Province fixed effects & Yes & Yes & Yes \\
\hline \multicolumn{4}{|c|}{$\begin{array}{l}\text { The dependent variable is the log-wage gap, defined as the log of the dif- } \\
\text { ference between the minimum wage and firm-level average wages. This } \\
\text { sub-sample refers to Non-compliant firms (with average wages below the } \\
\text { minimum wage), for the period 1991-1993. Standard errors are in paren- } \\
\text { theses, with *,** and *** indicating significance at the } 0.10,0.05 \text { and } \\
0.01 \text { levels respectively. A constant term is included in all specifications } \\
\text { but is not shown here. Standard errors are clustered at the District level. }\end{array}$} \\
\hline
\end{tabular}


Table 11: Placebo test: Panel Estimation, Post1994. Non-compliant firms.

Dependent variable: log-wage gap

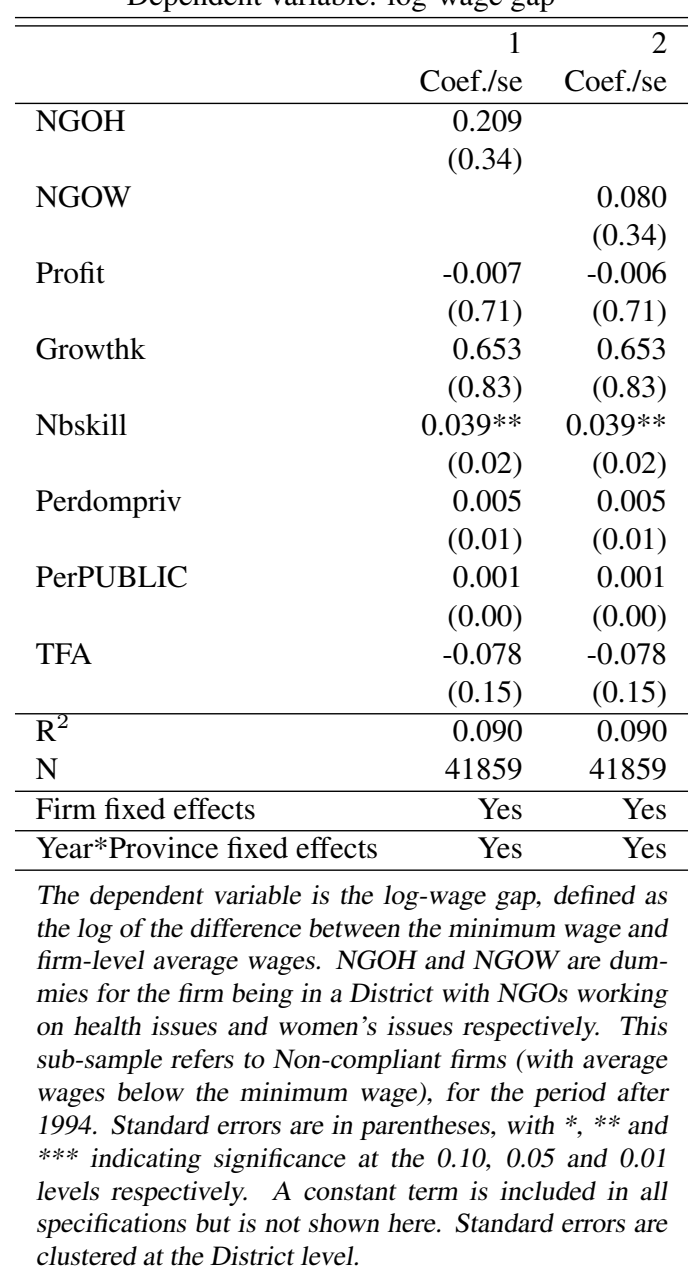


Table 12: Geographical determinants: Difference-in-Difference, 1991-1996. Non-compliant firms

Dependent variable: log-wage

\begin{tabular}{|c|c|c|c|}
\hline & 1 & 2 & 3 \\
\hline & Coef./se & Coef./se & Coef./se \\
\hline \multirow[t]{2}{*}{ NGO } & -0.100 & -0.100 & -0.087 \\
\hline & $(0.11)$ & $(0.11)$ & $(0.11)$ \\
\hline \multirow[t]{2}{*}{$\mathrm{T} * \mathrm{NGO}$} & $0.049 * *$ & $0.049 * *$ & $0.049 * *$ \\
\hline & $(0.02)$ & $(0.02)$ & $(0.02)$ \\
\hline \multirow[t]{2}{*}{ Profit } & -0.117 & -0.119 & -0.131 \\
\hline & $(0.37)$ & $(0.37)$ & $(0.37)$ \\
\hline \multirow[t]{2}{*}{ GrowthK } & 0.045 & 0.045 & 0.021 \\
\hline & $(0.29)$ & $(0.29)$ & $(0.29)$ \\
\hline \multirow[t]{2}{*}{ Nbskill } & $-0.051 * * *$ & $-0.051 * * *$ & $-0.051 * * *$ \\
\hline & $(0.01)$ & $(0.01)$ & $(0.01)$ \\
\hline \multirow{2}{*}{ Perdompriv } & & 0.000 & 0.001 \\
\hline & & $(0.00)$ & $(0.00)$ \\
\hline \multirow{2}{*}{ PerPUBLIC } & & 0.000 & 0.000 \\
\hline & & $(0.00)$ & $(0.00)$ \\
\hline \multirow[t]{2}{*}{ Sharefirmd } & & & -0.096 \\
\hline & & & $(0.17)$ \\
\hline \multirow[t]{2}{*}{ ShareFORfirmd } & & & $0.404 *$ \\
\hline & & & $(0.21)$ \\
\hline \multirow[t]{2}{*}{ ShareEXPfirmd } & & & 0.077 \\
\hline & & & $(0.09)$ \\
\hline \multirow[t]{2}{*}{ Profitpercapita } & & & 0.000 \\
\hline & & & $(0.00)$ \\
\hline $\mathrm{R}^{2}$ & 0.421 & 0.421 & 0.421 \\
\hline $\mathrm{N}$ & 66540 & 66540 & 66540 \\
\hline Firm fixed effects & Yes & Yes & Yes \\
\hline Year*Province fixed effects & Yes & Yes & Yes \\
\hline
\end{tabular}

The dependent variable is the log-wage, defined as the log of average wages at the firm level. This sub-sample refers to Non-compliant firms (with average wages below the minimum wage). Standard errors are in parentheses, with *,** and *** indicating significance at the $0.10,0.05$ and 0.01 levels respectively. A constant term is included in all specifications but is not shown here. Standard errors are clustered at the District level. 
Table 13: Geographical determinants: Panel Estimation, 19941996. Non-compliant firms

Dependent variable: log-wage gap

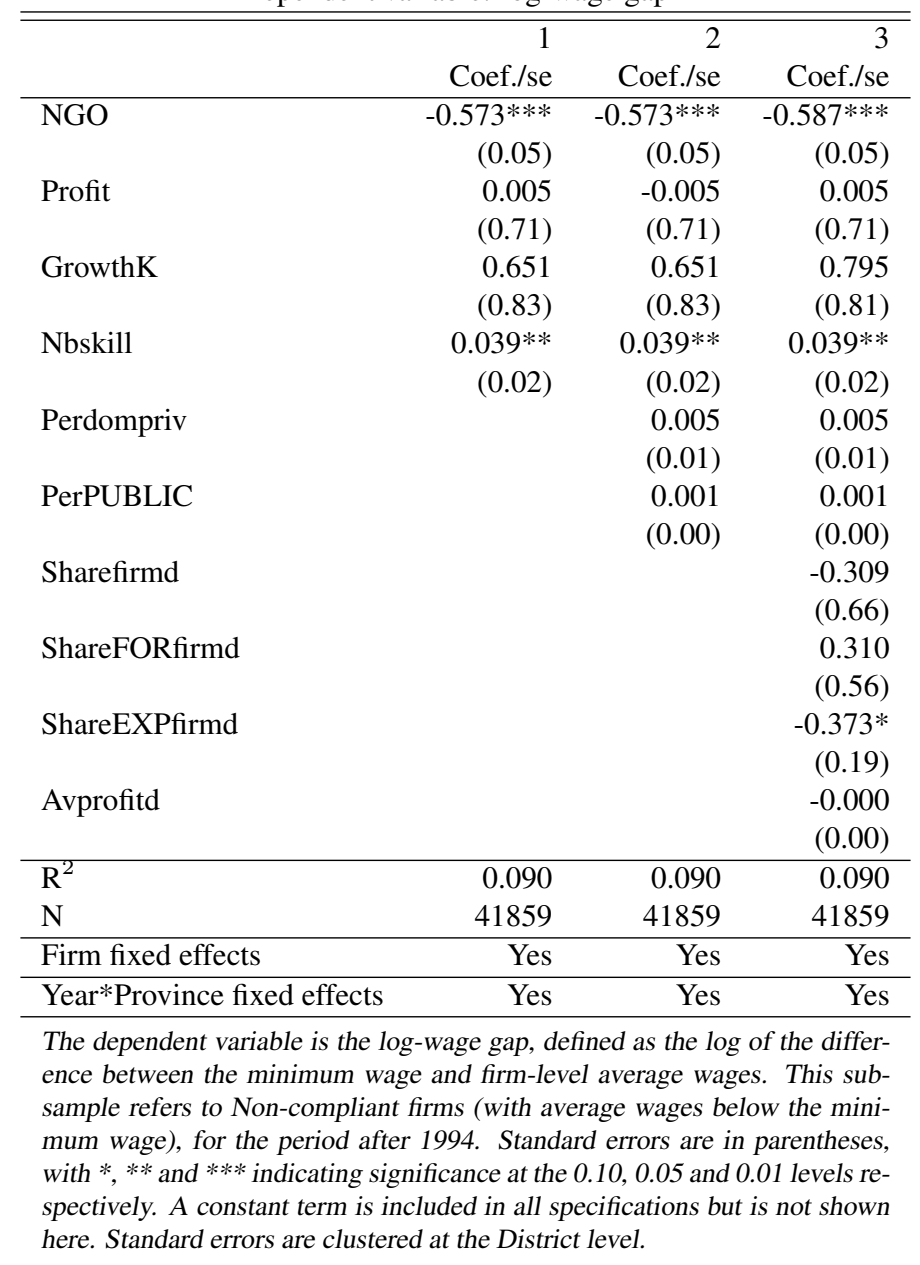


Table 14: Logit estimation

\begin{tabular}{|c|c|c|c|}
\hline \multicolumn{4}{|c|}{ Dependent variable: Non-compliant firms } \\
\hline & 1 & 2 & 3 \\
\hline & Coef./se & Coef./se & Coef./se \\
\hline \multirow[t]{2}{*}{ NGO } & -0.219 & -0.219 & -0.218 \\
\hline & $(0.30)$ & $(0.30)$ & $(0.30)$ \\
\hline \multirow[t]{2}{*}{$\mathrm{T} * \mathrm{NGO}$} & 0.080 & 0.080 & 0.080 \\
\hline & $(0.07)$ & $(0.07)$ & $(0.07)$ \\
\hline \multirow[t]{2}{*}{1992} & $-0.068 * *$ & $-0.068 * *$ & $-0.068 * *$ \\
\hline & $(0.03)$ & $(0.03)$ & $(0.03)$ \\
\hline \multirow[t]{2}{*}{1993} & -0.023 & -0.024 & -0.024 \\
\hline & $(0.03)$ & $(0.03)$ & $(0.03)$ \\
\hline \multirow[t]{2}{*}{1994} & $1.623 * * *$ & $1.621 * * *$ & $1.621 * * *$ \\
\hline & $(0.04)$ & $(0.04)$ & $(0.04)$ \\
\hline \multirow[t]{2}{*}{1995} & $2.066 * * *$ & $2.063 * * *$ & $2.064 * * *$ \\
\hline & $(0.04)$ & $(0.04)$ & $(0.04)$ \\
\hline \multirow[t]{2}{*}{1996} & $1.517 * * *$ & $1.514 * * *$ & $1.515 * * *$ \\
\hline & $(0.04)$ & $(0.04)$ & $(0.04)$ \\
\hline \multirow[t]{2}{*}{ Nbworker } & & 0.006 & 0.006 \\
\hline & & $(0.01)$ & $(0.01)$ \\
\hline \multirow[t]{2}{*}{ Profit } & & & -0.655 \\
\hline & & & (1.04) \\
\hline \multirow[t]{2}{*}{ GrowthK } & & & $2.509^{*}$ \\
\hline & & & $(1.52)$ \\
\hline \multicolumn{4}{|l|}{$\mathrm{R}^{2}$} \\
\hline $\mathrm{N}$ & 53809 & 53809 & 53804 \\
\hline Firm fixed effects & Yes & Yes & Yes \\
\hline Year fixed effects & Yes & Yes & Yes \\
\hline
\end{tabular}


Table 15: Geographical Determinants-Strikes: Panel Estimation, 1994-1996. Non-compliant firms

\begin{tabular}{|c|c|c|c|}
\hline \multicolumn{4}{|c|}{ Dependent variable: log-wage gap } \\
\hline & 1 & 2 & 3 \\
\hline & Coef./se & Coef./se & Coef./se \\
\hline \multirow[t]{2}{*}{ NGO } & $-0.587 * * *$ & $-0.343^{* *}$ & $-0.377 * *$ \\
\hline & $(0.05)$ & $(0.14)$ & $(0.16)$ \\
\hline \multirow{2}{*}{ Profit } & 0.005 & 0.003 & -0.054 \\
\hline & $(0.71)$ & $(0.71)$ & $(0.79)$ \\
\hline \multirow[t]{2}{*}{ GrowthK } & 0.795 & 0.791 & 0.467 \\
\hline & $(0.81)$ & $(0.81)$ & $(0.75)$ \\
\hline \multirow[t]{2}{*}{ Nbskill } & $0.039 * *$ & $0.039 * *$ & $0.047 * *$ \\
\hline & $(0.02)$ & $(0.02)$ & $(0.02)$ \\
\hline \multirow[t]{2}{*}{ Perdompriv } & 0.005 & 0.005 & 0.006 \\
\hline & $(0.01)$ & $(0.01)$ & $(0.01)$ \\
\hline \multirow[t]{2}{*}{ PerPUBLIC } & 0.001 & 0.001 & 0.001 \\
\hline & $(0.00)$ & $(0.00)$ & $(0.00)$ \\
\hline \multirow[t]{2}{*}{ Sharefirmd } & -0.309 & -0.294 & -0.443 \\
\hline & $(0.66)$ & $(0.66)$ & $(0.58)$ \\
\hline \multirow[t]{2}{*}{ ShareFORfirmd } & 0.310 & 0.317 & 0.054 \\
\hline & $(0.56)$ & $(0.55)$ & $(0.54)$ \\
\hline \multirow[t]{2}{*}{ ShareEXPfirmd } & $-0.373 *$ & $-0.374 * *$ & -0.277 \\
\hline & $(0.19)$ & $(0.19)$ & $(0.18)$ \\
\hline \multirow[t]{2}{*}{ Profitpercapita } & -0.000 & -0.000 & -0.000 \\
\hline & $(0.00)$ & $(0.00)$ & $(0.00)$ \\
\hline \multirow[t]{2}{*}{ Strike } & & $-0.523^{*}$ & $-0.563 * *$ \\
\hline & & $(0.28)$ & $(0.28)$ \\
\hline $\mathrm{R}^{2}$ & 0.090 & 0.090 & 0.138 \\
\hline $\mathrm{N}$ & 41859 & 41859 & 41859 \\
\hline Firm fixed effects & Yes & Yes & Yes \\
\hline Year*Province fixed effects & Yes & Yes & Yes \\
\hline Year*Sector fixed effects & No & No & Yes \\
\hline
\end{tabular}

The dependent variable is the log-wage gap, defined as the log of the difference between the minimum wage and firm-level average wages. This sub-sample refers to Non-compliant firms (with average wages below the minimum wage), for the period after 1994. Standard errors are in parentheses, with *,** and *** indicating significance at the $0.10,0.05$ and 0.01 levels respectively. A constant term is included in all specifications but is not shown here. Standard errors are clustered at the District level. 
Table 16: Geographical Determinants: Panel Estimation, 19941996. Non-compliant firms in Districts with strikes

\begin{tabular}{lrrr}
\multicolumn{4}{c}{ Dependent variable: log-wage gap } \\
\hline \hline \multirow{4}{*}{ NGO } & 1 & 2 & 3 \\
& Coef./se & Coef./se & Coef./se \\
Profit & $-0.641^{* * *}$ & $-0.662^{* * *}$ & $-0.754^{* * *}$ \\
& $(0.07)$ & $(0.07)$ & $(0.13)$ \\
GrowthK & 0.036 & 0.057 & 0.342 \\
& $(0.65)$ & $(0.69)$ & $(0.89)$ \\
Nbskill & 2.447 & 2.525 & 2.949 \\
& $(4.67)$ & $(4.70)$ & $(5.49)$ \\
Perdompriv & 0.016 & 0.015 & 0.020 \\
& $(0.01)$ & $(0.01)$ & $(0.01)$ \\
PerPUBLIC & 0.003 & 0.002 & 0.007 \\
& $(0.01)$ & $(0.01)$ & $(0.02)$ \\
Sharefirmd & 0.000 & 0.000 & 0.001 \\
& $(0.00)$ & $(0.00)$ & $(0.00)$ \\
ShareFORfirmd & & -0.001 & 0.293 \\
& & $(1.25)$ & $(1.08)$ \\
ShareEXPfirmd & & -1.768 & $-2.442^{*}$ \\
& & $(1.03)$ & $(1.29)$ \\
Profitpercapita & & 0.809 & 1.113 \\
& & $(0.64)$ & $(0.77)$ \\
\hline R ${ }^{2}$ & & -0.000 & -0.000 \\
$\mathrm{~N}$ & & $(0.00)$ & $(0.00)$ \\
\hline Firm fixed effects & Yes & 0.090 & 0.185 \\
\hline Year*Province fixed effects & & Yes & Yes \\
\hline Year*Sector fixed effects & & No & Yes \\
\hline
\end{tabular}

The dependent variable is the log-wage gap, defined as the log of the difference between the minimum wage and firm-level average wages. This subsample refers to Non-compliant firms (with average wages below the minimum wage). We only consider here firms in Districts with strikes in the 1994-1996 period. Standard errors are in parentheses, with *, ** and *** indicating significance at the $0.10,0.05$ and 0.01 levels respectively. A constant term is included in all specifications but is not shown here. Standard errors are clustered at the District level. 
Table 17: The location of Indonesian Labor NGOs by Districts

\begin{tabular}{lr} 
Organisation & Location \\
\hline Labor NGOs Formed by Ex-Unionists & \\
\hline Yayasan Bina Kariah (YBK) & Bandung \\
Yyasan Buruh Mambangun (YBM) & Jakarta \\
\hline Labor NGOs Formed by Worker Activists & \\
\hline Yayasan Bhakti Pertiwi & Jakarta \\
Kelompok Buruh Bandung (KBB) & Bandung \\
\hline Christian Labor NGOs & Jakarta \\
\hline Lembaga Daya Dharma (LDD) & Jakarta \\
Institut Perburuhan Jakarta (ISJ/IPJ) & Jakarta \\
Pelayan Buruh Jakarta (PMK/PBJ) & Jakarta \\
Sisbikum & Jakarta \\
Yayasan Forum Adil Sejantera (YFAS) & \\
\hline Student-Based Labor NGOs & Surabaya \\
\hline Yayasan Arek Surabaya & Surabaya \\
Kelompok Kerja Humanika & Medan \\
Kelompok Pelita Sejantera (KPS) & Jakarta \\
Yayasan Maju Bersama (YMB) & \\
\hline Feminist Grassroots Labor NGOs & Yogyakarta \\
\hline Yasanti & Jakarta \\
Yayasan Perempuan Mardika (YPM) & \\
\hline Legal Aid NGOs with a Labor Focus & Jakarta \\
\hline LBH Jakarta & Bandung \\
LBH Bandung & Surabaya \\
LBH Surabaya & Jakarta \\
\hline LBH Apik & Bogor \\
\hline Research and Policy NGOs with a Labor Focus & Bandung \\
\hline LIPS & Yogyakarta \\
Akatiga & Jakarta \\
Lapera & \\
ELSAM & \\
Solidaritas Perumpuan & \\
\hline &
\end{tabular}

